\title{
Eastern dobsonfly (adult), hellgrammite (larva) Corydalus cornutus (Linnaeus) (Insecta: Megaloptera: Corydalidae: Corydalinae) ${ }^{1}$
}

Donald W. Hall ${ }^{2}$

\section{Introduction}

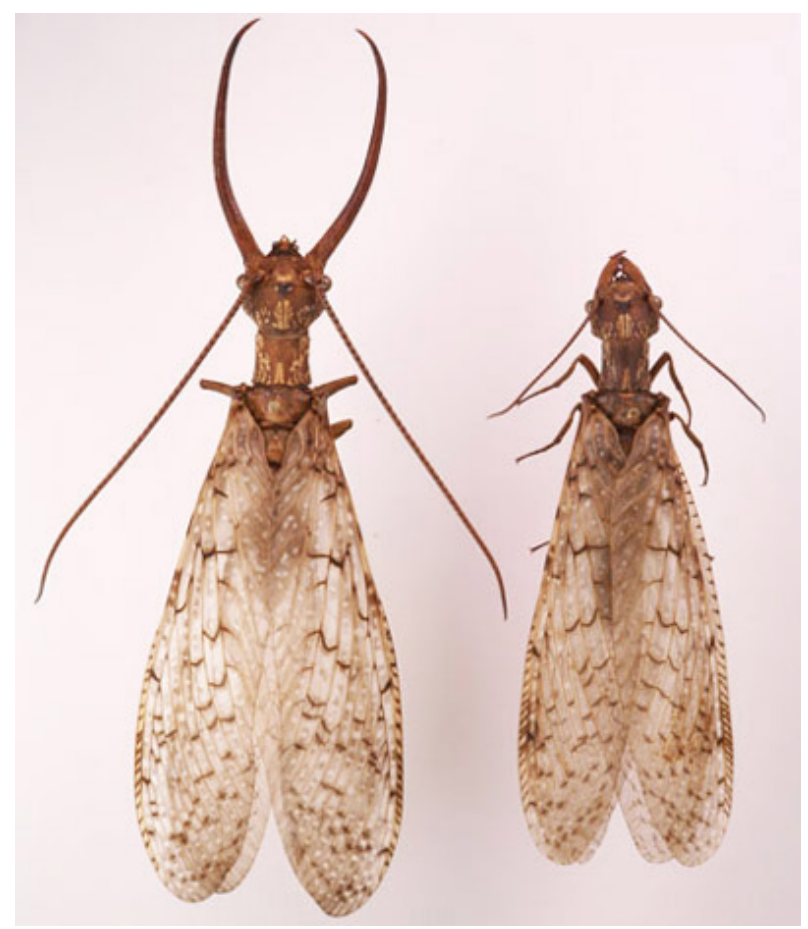

Figure 1. Male and female eastern dobsonflies, Corydalus cornutus (Linnaeus), showing differences in mandibles and antennae.

Credits: Lyle J. Buss, University of Florida.

The eastern dobsonfly, Corydalus cornutus (Linnaeus), is one of our largest non-lepidopteran insects. Its larvae, known as hellgrammites, are the top invertebrate predators in rocky streams where they occur. Adult male dobsonflies are particularly spectacular because of their large sickleshaped mandibles (jaws). There is a total of thirty species of Corydalus (Contreras-Ramos 1997), mostly from South America. In addition to the eastern dobsonfly, Corydalus cornutus, there are three dobsonflies of the genus Corydalus in the western U.S. For simplicity, the term "dobsonfly" throughout the remainder of this publication will refer to the eastern dobsonfly, Corydalus cornutus.

\section{Distribution}

The dobsonfly is found throughout most of eastern North America east of the Continental Divide from Canada to Mexico near flowing streams which provide habitat for its larvae.

\section{Description}

\section{Eggs}

Dobsonfly eggs are gray, cylindrical and a little less than 1.5 $\mathrm{mm}$ in length and $0.5 \mathrm{~mm}$ in width. They are laid in clusters (about $2 \mathrm{~cm}$ in diameter) with an average of approximately 1,000 eggs/cluster (Baker and Neunzig 1968, Mangan 1992.). The eggs are arranged in three layers, and the egg mass is covered with a clear fluid by a brushing motion of the tip of the female's abdomen. The clear fluid dries to a white color. Superficially, the egg masses resemble large bird droppings.

1. This document is EENY 414, one of a series of the Entomology and Nematology Department, Florida Cooperative Extension Service, Institute of Food and Agricultural Sciences, University of Florida. Original publication date July 2007. Revised April 2013. Visit the EDIS website at http://edis.ifas.ufl.edu.

2. Donald W. Hall, professor, Entomology and Nematology Department, Institute of Food and Agricultural Sciences, University of Florida, Gainesville, FL 32611. 


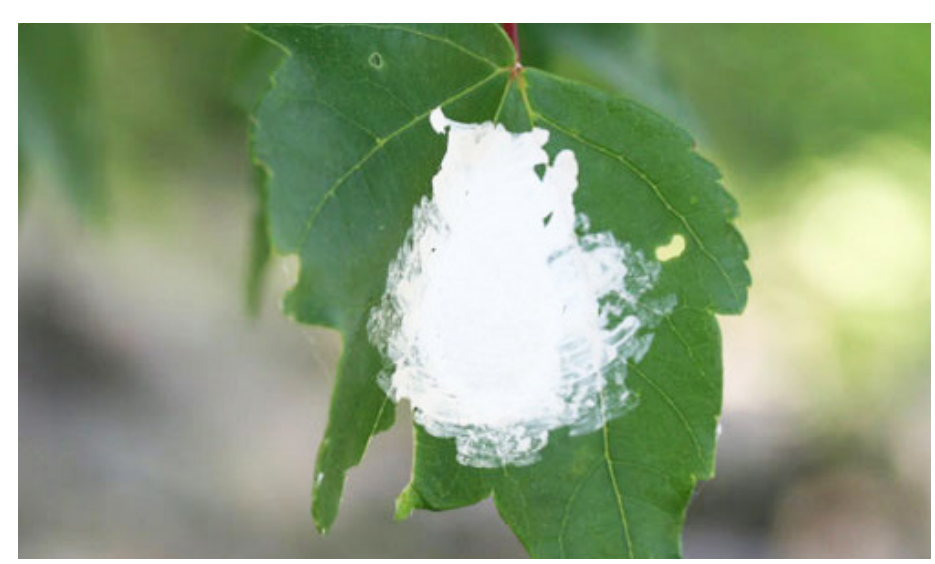

Figure 2. Eastern dobsonfly, Corydalus cornutus (Linnaeus), egg mass showing "brush strokes" of white coating. Credits: D.W. Hall, University of Florida.

\section{Larva}

Dobsonfly larvae (75 to $90 \mathrm{~mm}$ in length) are light brown and darkened by a covering of dark brown microspines (Neunzig and Baker 1991). The thoracic segments are covered with hardened, black tergites (dorsal plates).

Abdominal segments 1 through 8 have lateral tactile filaments which function to protect them from each other and from other small predators (Neunzig and Baker 1991), and segments 1 through 7 each has a pair of ventro-lateral tufts of tracheal gills that absorb dissolved oxygen (Barclay et al. 2005, Hoover et al. 1988). In addition to the tracheal gills, larvae also have spiracles allowing them to breathe both in and out of water. There are two prolegs at the tip of the abdomen -- each with a dorsal filament and a pair of terminal hooks to help the larvae anchor themselves to the substrate. The mandibles are powerful and heavily sclerotized.

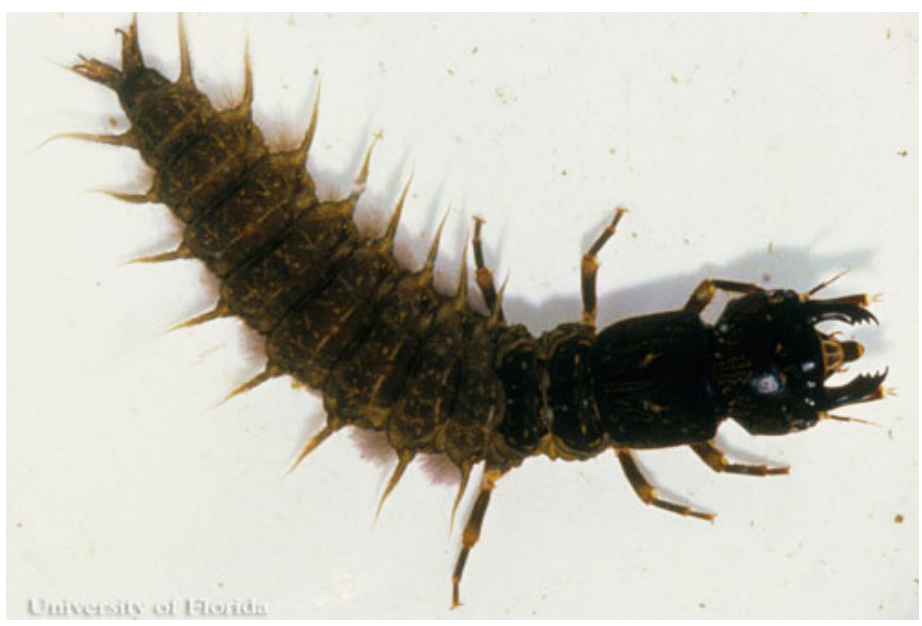

Figure 3. Larva of the eastern dobsonfly, Corydalus cornutus (Linnaeus). Credits: J.F. Butler, University of Florida.

\section{Pupae}

Dobsonfly pupae are exarate (the developing wings, legs, antennae and mouthparts are attached only at their proximal ends) and yellow-orange in coloration with darker splotches on the dorsum of the abdomen. They are covered with minute setae. Male pupae have a small tubercle on the sternum of the prothorax and have slightly larger mandibles and wider head capsules than females, (Mangan 1994), but the mandibles of the sexes are not markedly dimorphic as in the adults. Parfin (1952) reported that the long mandibles of the male are folded up like an accordion in the pupal exoskeleton.

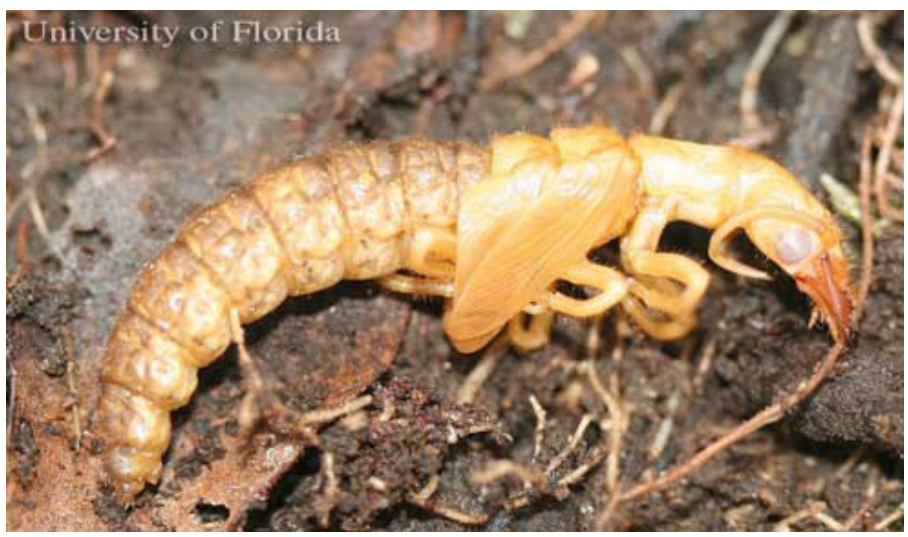

Figure 4. Pupa of the eastern dobsonfly. Corydalus cornutus (Linnaeus). Credits: D.W. Hall, University of Florida.

\section{Adults}

Adult dobsonflies are large insects, 100 to $140 \mathrm{~mm}$ (Arnett 2000), with large wings from which the order name Megaloptera (large wing) is derived. The female has short powerful mandibles similar in size to those of the larva and is capable of drawing blood with her bite. The male has long, sickle-shaped mandibles (up to $40 \mathrm{~mm}$ in length) and is incapable of inflicting a painful bite.

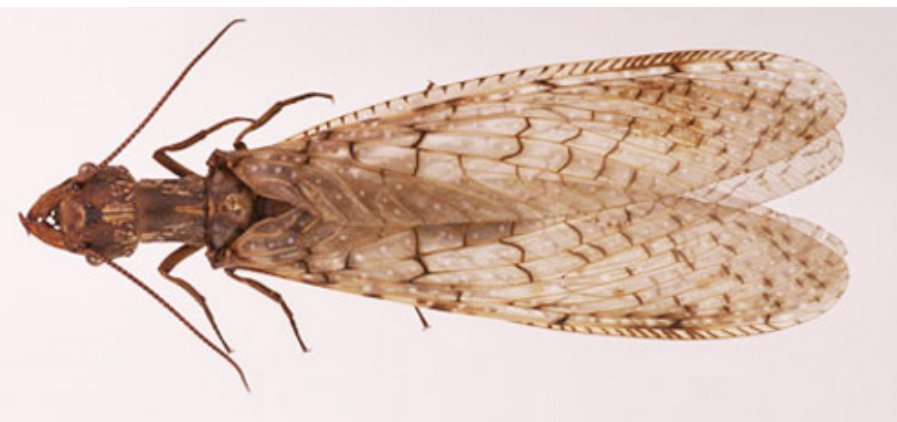

Figure 5. Adult female eastern dobsonfly, Corydalus cornutus (Linnaeus).

Credits: Photograph by Lyle J. Buss, University of Florida. 


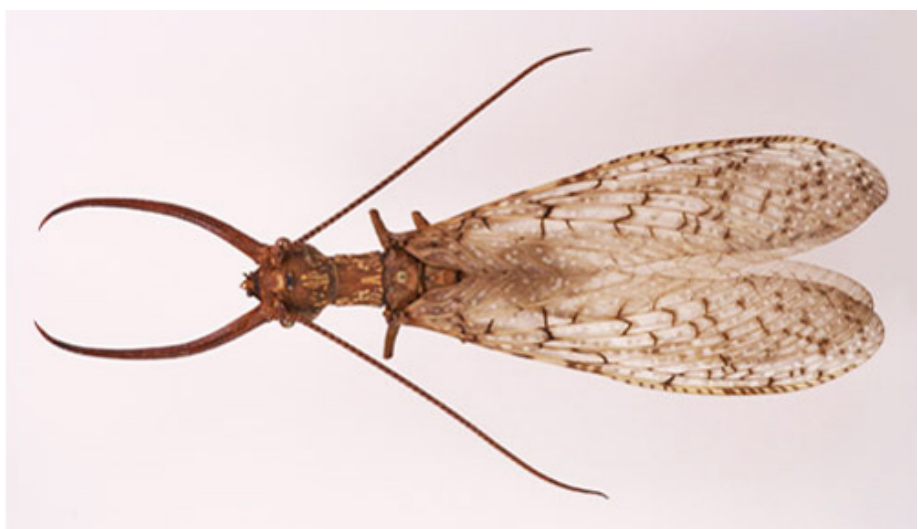

Figure 6. Adult male eastern dobsonfly, Corydalus cornutus (Linnaeus). Credits: Lyle J. Buss, University of Florida.

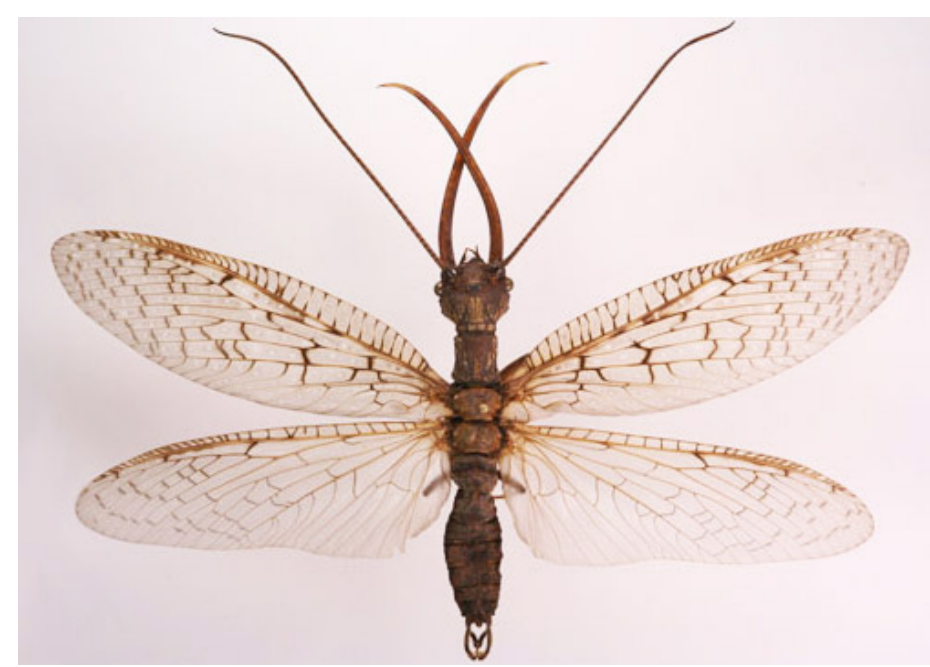

Figure 7. Adult male eastern dobsonfly, Corydalus cornutus (Linnaeus), with wings spread.

Credits: Lyle J. Buss, University of Florida.

\section{Life Cycle and Biology}

Dobsonfly eggs hatch in 1 to 2 weeks and always at night. The newly hatched hellgrammites are often buoyed by an air bubble and float or swim until reaching a suitable site for larval development - most often a swift-flowing part of the stream with a rocky bottom.

The hellgrammites live under stones or occasionally on snags where they feed on a variety of soft-bodied insects (often immatures of net-spinning caddisflies and blackflies) (McCafferty and Provonsha 1983). In captivity, they will feed on midge larvae or commercial aquarium fish foods such as freeze-dried tubifex worms or fish food flakes (Hoover et al 1988). Helgrammites molt (shed their exoskeletons) 10 to 12 times and require one to three years to complete their development.

When ready to pupate, hellgrammites leave the water and may pupate close to the water or travel up to 15 meters or more in search of a suitable site for pupation (Mangan
1994) - typically under a rock, log, or some type of debris that serves to maintain a moist environment. Exodus from the water of full-grown hellgrammites in a given location is fairly synchronous (within a few days). Voshell (2002) states that local residents along Virginia rivers report that thunderstorms trigger emergence of the hellgrammites - a phenomenon known locally as "hellgrammite crawling". It is believed that the behavior is stimulated by the vibrations from the thunder.

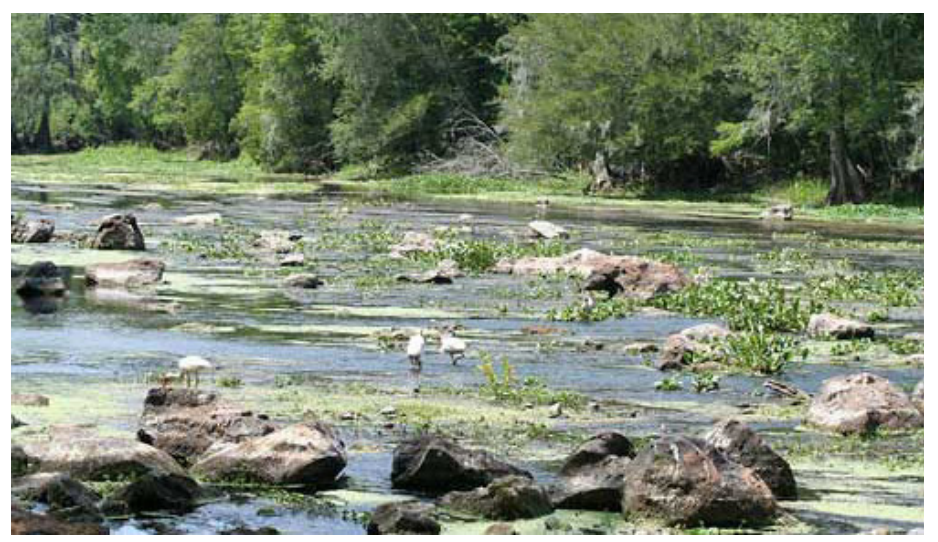

Figure 8. Eastern dobsonfly, Corydalus cornutus (Linnaeus), hellgrammite habitat - Santa Fe River (dry season), Alachua County, Florida. Credits: D.W. Hall, University of Florida

Upon reaching a suitable site for pupation, the hellgrammite typically digs a cell in the soil with its legs and mouthparts and smooths the interior by pressing the sides of its body against the wall of the cell. Hellgrammites have no silk glands; consequently, there is no silk or cocoon lining the cell. After spending one to 14 days inside the cell as a prepupa, the hellgrammite sheds its exoskeleton to become a pupa. The pupal stage requires seven to 14 days after which the adult emerges and digs its way out of the cell.

Adult dobsonflies are short-lived (about three days for males and eight to 10 days for females). It is generally believed that they do not feed in nature, but Parfin (1952) has reported that they will take a 3:1 mixture of honey water in captivity. She also reports that several entomologists have collected them at fermenting baits painted on tree trunks. The adults are active at night and are strongly attracted to lights. Otherwise they spend most of their time in thick vegetation near streams.

Parfin (1952) and Simonsen et al. (2008) have given detailed descriptions of the mating behavior of dobsonflies. As part of the premating ritual, males place their elongated jaws on the wings of the females perpendicular to the axis of the female's wings. The male's jaws also function in jousting with rival males. However, males were not observed to grasp the females as reported in older literature. 
Females lay their eggs on surfaces overhanging the water such as bridge abutments and the leaves, branches or trunks of trees (Mangan 1992). The egg masses are not randomly distributed, but rather they tend to occur in patches suggesting the possibility of an oviposition pheromone (Mangan 1992).

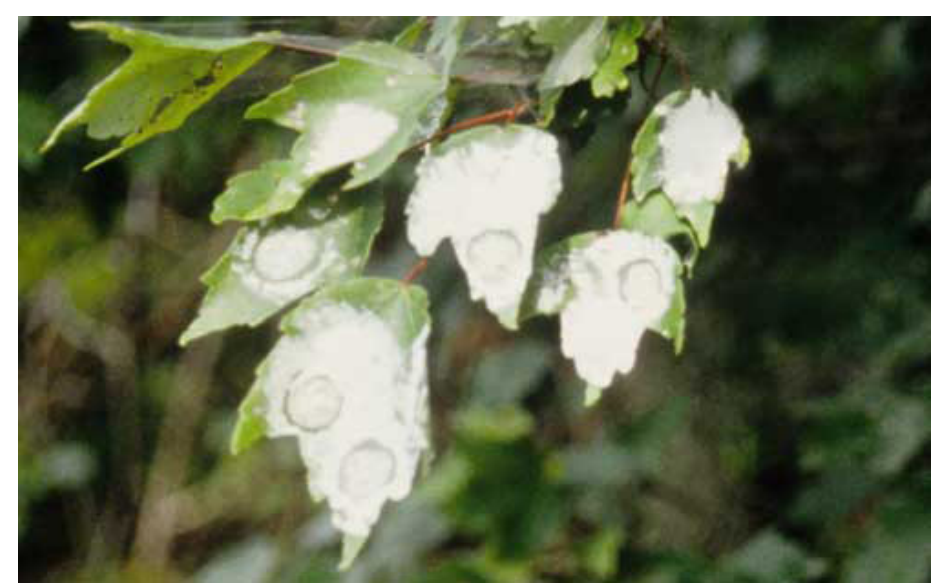

Figure 9. Patch of eastern dobsonfly, Corydalus cornutus (Linnaeus), egg masses on leaves of red maple.

Credits: D.W. Hall, University of Florida.

Mangan (1992) presented evidence that the white covering of the egg mass helps protect the eggs from overheating. It is also possible that the covering may function to protect the eggs from predation.

Dobsonflies are beneficial insects and should be conserved. Hellgrammites are prized as bait by fishermen (particularly for smallmouth bass) and are available for sale at bait shops in some areas. Because of the effort required to collect them, they are fairly expensive to purchase. Therefore, they may be subject to over-exploitation and their collection for sale is regulated in some states. Although, hellgrammites are great fish bait, they are rarely found in the stomachs of fish - probably because they spend most of their time under rocks where they are inaccessible.

Hellgrammites tend to be found in relatively unpolluted water. Therefore, they may have value in bio-monitoring studies (Voshell 2002). Perhaps their greatest value may be their contribution to biodiversity in their habitat as predators.

\section{Selected References}

Arnett Jr. RH. 2000. American Insects: A Handbook of the Insects of America North of Mexico. CRC Press. Boca Raton, Florida. 1003 pp.

Contreras-Ramos A. (1997). Corydalus. Tree of Life Web Project. http://www.tolweb.org/Corydalus (17 April 2013).

Baker JR, Neunzig HH. 1968. The egg masses, eggs and first-instar larvae of the eastern North American Corydalidae. Annals of the Entomological Society of America 61: 1181-1187.

Barclay A, Portman RW, Hill PSM. 2005. Tracheal gills of the dobsonfly larvae, or hellgrammite Corydalus cornutus L. (Megaloptera: Corydalidae). Journal of the Kansas Entomological Society 78: 181-185.

Hoover JJ, Gage KL, Paulissen MS. 1988. Hellgrammite respiration - temperature's role in ectotherm physiology. The American Biology Teacher 50: 39-42.

Mangan BP. 1992. Oviposition of the dobsonfly (Corydalus cornutus, Megaloptera) on a large river. American Midland Naturalist 127: 348-354.

Mangan BP. 1994. Pupation ecology of the dobsonfly Corydalus cornutus (Corydalidae: Megaloptera) along a large river. Journal of Freshwater Ecology 9: 57-62.

McCafferty WP Provonsha AV. 1983. Aquatic Entomology: The Fisherman's and Ecologist's Illustrated Guide to Insects and Their Relatives. Jones and Bartlett Publishers, Inc. Portola Valley, California. 448 pp.

Neunzig HH Baker JR. Order Megaloptera. 1991. In Stehr, FW, editor. Immature Insects, Vol. 2. Kendall/Hunt Publishing Company. Dubuque, Iowa. pp. 112-122.

Parfin S. 1952. Notes on the bionomics of Corydalus cornutus (Linne), Chauliodes rastricornis Rambur, $C$. pectinicornis (Linne) and Neohermes sp. American Midland Naturalist 47: 426-434.

Simonsen TJ, Dombroskie JJ, Lawrie DD. 2008. Behavioral observations on the dobsonfly, Corydalus cornutus (Megaloptera: Corydalidae) with photographic evidence of the use of the elongate mandibles in the male. American Entomologist 54: 167-169.

Voshell JR. 2002. A Guide to Common Freshwater Invertebrates of North America. The McDonald \& Woodward Publishing Company. Blacksburg, Virginia. 442 pp. 